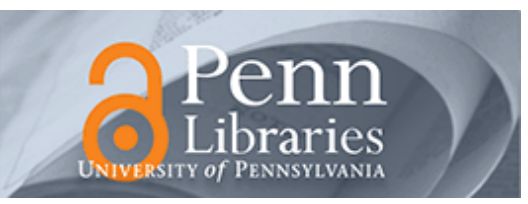

University of Pennsylvania ScholarlyCommons

September 2004

\title{
From dinosaurs to dyrosaurids (Crocodyliformes): Removal of the post-Cenomanian (Late Cretaceous) record of Ornithischia from Africa
}

\author{
Matthew C. Lamanna \\ University of Pennsylvania \\ Joshua B. Smith \\ University of Pennsylvania,wjsmith@sas.upenn.edu \\ Yousry S. Attia \\ Egyptian Geological Survey and Mining Authority \\ Peter Dodson \\ University of Pennsylvania, dodsonp@vet.upenn.edu
}

Follow this and additional works at: https://repository.upenn.edu/ees_papers

\section{Recommended Citation}

Lamanna, M. C., Smith, J. B., Attia, Y. S., \& Dodson, P. (2004). From dinosaurs to dyrosaurids (Crocodyliformes): Removal of the post-Cenomanian (Late Cretaceous) record of Ornithischia from Africa . Retrieved from https://repository.upenn.edu/ees_papers/31

Copyright The Society of Vertebrate Paleontology. Use for profit not allowed. Reprinted from: Journal of Vertebrate Paleontology, Volume 24, Issue 3, 2004, pages 764-768.

Publisher URL: http://www.vertpaleo.org/

This paper is posted at ScholarlyCommons. https://repository.upenn.edu/ees_papers/31

For more information, please contact repository@pobox.upenn.edu. 


\title{
From dinosaurs to dyrosaurids (Crocodyliformes): Removal of the post- Cenomanian (Late Cretaceous) record of Ornithischia from Africa
}

\author{
Abstract \\ Ornithischian dinosaurs are uncommon elements in Late Cretaceous faunal assemblages of many \\ Gondwanan landmasses, particularly Africa. The best-documented post-Cenomanian record of purported \\ ornithischian body fossils from Africa consists of a left humerus, with associated cranial and costal \\ fragments, from the Santonian-Campanian Quseir Formation of Kharga Oasis, Egypt (Fig. 1 ) (Awad and \\ Ghobrial, 1966). We show that this specimen pertains instead to a dyrosaurid crocodyliform, and restrict \\ known African ornithischian body fossils to pre-Turonian sediments. The apparent absence of this \\ dinosaur clade from the post-Cenomanian Late Cretaceous of Africa is probably a consequence of limited \\ sampling; nevertheless, a comparable ornithischian absence from coeval sediments in Madagascar and \\ possibly Indo-Pakistan constitutes a notable faunal similarity among these landmasses.

\section{Comments} \\ Copyright The Society of Vertebrate Paleontology. Use for profit not allowed. Reprinted from: Journal of \\ Vertebrate Paleontology, Volume 24, Issue 3, 2004, pages 764-768. \\ Publisher URL: http://www.vertpaleo.org/
}




\title{
FROM DINOSAURS TO DYROSAURIDS (CROCODYLIFORMES): REMOVAL OF THE POST-CENOMANIAN (LATE CRETACEOUS) RECORD OF ORNITHISCHIA FROM AFRICA
}

\author{
MATTHEW C. LAMANNA ${ }^{1 *}$, JOSHUA B. SMITH ${ }^{1 * *}$, YOUSRY S. ATTIA ${ }^{3}$, and PETER DODSON ${ }^{2}$, ${ }^{1}$ Department of Earth and \\ Environmental Science, University of Pennsylvania, 240 South 33rd Street, Philadelphia, Pennsylvania 19104 USA; lamanna@sas.upenn.edu; \\ ${ }^{2}$ Department of Animal Biology, School of Veterinary Medicine, University of Pennsylvania, 3800 Spruce Street, Philadelphia, Pennsylvania \\ 19104 USA; ${ }^{3}$ Egyptian Geological Museum, Egyptian Geological Survey and Mining Authority, Athar El Nabi, Maadi, Cairo, Egypt
}

Ornithischian dinosaurs are uncommon elements in Late Cretaceous faunal assemblages of many Gondwanan landmasses, particularly Africa. The best-documented post-Cenomanian record of purported ornithischian body fossils from Africa consists of a left humerus, with associated cranial and costal fragments, from the Santonian-Campanian Quseir Formation of Kharga Oasis, Egypt (Fig. 1) (Awad and Ghobrial, 1966). We show that this specimen pertains instead to a dyrosaurid crocodyliform, and restrict known African ornithischian body fossils to pre-Turonian sediments. The apparent absence of this dinosaur clade from the postCenomanian Late Cretaceous of Africa is probably a consequence of limited sampling; nevertheless, a comparable ornithischian absence from coeval sediments in Madagascar and possibly Indo-Pakistan constitutes a notable faunal similarity among these landmasses.

Institutional Abbreviations-CGM, Egyptian Geological Museum, Cairo; MRAC, Musée Royal d'Afrique Central, Tervuren, Belgium; USGS SAP, United States Geological Survey, Saudi Arabian Collection, Saudi Arabia; YPM, Yale Peabody Museum, New Haven.

Anatomical Abbreviations-dpc, deltopectoral crest; hd, humeral head; rac, radial condyle; ulc, ulnar condyle.

\section{SYSTEMATIC PALEONTOLOGY}

\section{CROCODYLOMORPHA Walker, 1970} CROCODYLIFORMES Hay, 1930

MESOEUCROCODYLIA Whetstone and Whybrow, 1983 DYROSAURIDAE de Stefano, 1903

Referred Specimen-CGM 30975, a complete left humerus (Figs. 2, $3 \mathrm{~A}$, Table 1), associated with fragments of the cranium and dorsal ribs (Awad and Ghobrial, 1966).

Locality-Approximately four kilometers east of the road between Gaga and Baris, southern Kharga Oasis, Western Desert of Egypt (paraphrased from Awad and Ghobrial [1966]; approximately $24^{\circ} 44^{\prime} \mathrm{N}, 30^{\circ}$ $37^{\prime}$ E) (Fig. 1). We recognize the inadequacy of this description; nevertheless, the stratigraphic provenance of CGM 30975 is known with certainty.

Horizon and Age-Quseir Formation (="variegated shale" of the Nubia Formation [Awad and Ghobrial, 1966; Weishampel, 1990]; $=$ Baris Formation [Hendriks et al., 1987]), Santonian-Campanian (Late Cretaceous) (Churcher, 1995; Mahmoud, 1998).

Description-The humerus is elongate and slender, bowed ventrally, and modestly expanded at its proximal and distal extremes. There is slight torsion between the ends of the element. As seen in ventral view, the proximal margin of the humerus forms an approximate right angle with the lateral surface of the shaft, resulting in a distinctive "squared"

\footnotetext{
* Present address: Section of Vertebrate Paleontology, Carnegie Museum of Natural History, 4400 Forbes Avenue, Pittsburgh, Pennsylvania 15213, lamannam@carnegiemnh.org

** Present address: Department of Earth and Planetary Sciences, Washington University, 1 Brookings Drive, Campus Box 1169, 108 Wilson Hall, St. Louis, Missouri 63130
}

appearance (Fig. 2A, 3A). The slightly abraded deltopectoral crest extends more than one-third the length of the humerus, but is low throughout its length. The hemispherical humeral head projects from the dorsal surface of the proximal end of the element (Fig. 2B). The medial margin of the shaft is shallowly concave through its proximal third but essentially straight distally. The distal end of the humerus flares laterally and is nearly as transversely expanded as the proximal portion (Table 1 ). The cranial and rib fragments associated with the specimen could not be located for study.

\section{DISCUSSION}

Post-Cenomanian African Ornithischian Absence-CGM 30975 was originally recognized as an ornithischian dinosaur humerus (Awad and Ghobrial, 1966:pl. IV; El-Kashab, 1977; Klitzsch et al., 1979; Weishampel, 1990; Gomani, 1999). If accurately identified, the specimen would be of importance, as reliable records of Ornithischia are unknown from post-Cenomanian deposits in Africa. Ichnites from the Turonian of southern Egypt were tentatively referred to a small ornithischian; however, the poor preservation of these specimens renders their identification uncertain (Demathieu and Wycisk, 1990). Mateer et al. (1992), citing Furon (1963), reported the occurrence of the Jurassic dryosaurid ornithopod Dryosaurus sp. in Late Cretaceous deposits of Mali. This record was emended to Dryosauridae indet. by Gomani (1999). However, Furon (1963) mentioned only sauropod and theropod dinosaur material from the Cretaceous deposits in question, and the dyrosaurid crocodyliform Dyrosaurus from overlying Paleocene sediments. We believe that, given the similarity of their generic names, Mateer et al. (1992) unintentionally transposed Furon's (1963) report of the crocodyliform Dyrosaurus for the ornithopod Dryosaurus. Assuming that nonavian dinosaurs did not survive into the Paleocene, Mateer et al. (1992) assigned the specimen to the Late Cretaceous. Mateer (pers. comm., 2002) has recently acknowledged this possibility. The record of Ornithischia in the Late Cretaceous of Mali is therefore probably invalid.

Putative ornithopod caudal vertebrae were reported from the purportedly Upper Cretaceous Ameki Formation of Nigeria (Nopcsa, 1925; Molnar, 1980). However, these sediments were subsequently shown to be Eocene in age (see Arua and Rao, 1987), and the specimens in question pertain to a dyrosaurid crocodyliform (Swinton, 1930).

Weishampel (1990), Jacobs et al. (1996), and Gomani (1999) noted indeterminate ornithopod remains from the Turonian-Santonian of Kenya. Weishampel (1990) cited an unpublished manuscript by J. M. Harris and D. A. Russell. However, according to Russell (pers. comm., 2002), the specimens mentioned therein are fragmentary, were observed only in the field and never collected, may be pre-Turonian (?Cenomanian) in age, and cannot be confidently assigned to Ornithischia. Jacobs et al. (1996) and Gomani (1999) cite Wescott et al. (1993), who note only "dinosaur bones" from the deposits in question. Similarly, Arambourg and Wolff (1969), cited by Gomani (1999), mention only possible sauropod bones. In summary, there is no firm evidence of ornithischians in the Late Cretaceous of Kenya.

Comparison with Ornithischia-To elucidate its affinities, we compared the Egyptian humerus with several Cretaceous tetrapod clades, including Ornithischia. CGM 30975 bears little resemblance to the hu- 


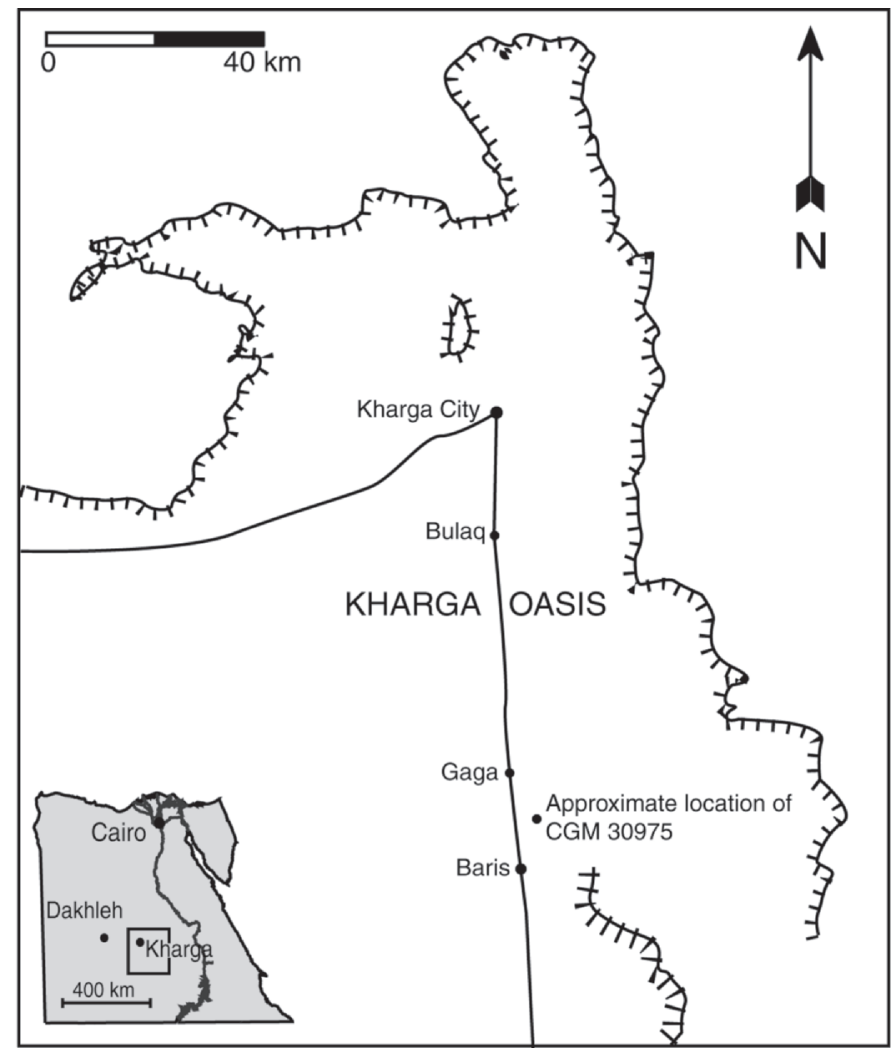

FIGURE 1. Location of discovery of CGM 30975, Kharga Oasis, Western Desert of Egypt.

meri of Cretaceous thyreophorans and ceratopsians. It does somewhat resemble the humerus of the pachycephalosaur Goyocephale (Fig. 3B; Perle et al., 1982), but in that taxon the humerus is more robust, with a strongly expanded and medially deflected proximal portion. Furthermore, as pachycephalosaurs appear restricted to Northern Hemisphere landmasses (Sampson et al., 1998), we regard affinity with that clade as unlikely.

Among ornithischians, CGM 30975 most closely resembles ornithopod humeri. We compared the Quseir specimen to Cretaceous representatives of Ornithopoda from elsewhere in North Africa and the geographically proximal landmasses of Europe, South America, and Antarctica. In the Early Cretaceous North African iguanodontian Ouranosaurus (Fig. 3C; Taquet, 1976) and the Late Cretaceous Argentine ornithopods Anabisetia (Coria and Calvo, 2002), Gasparinisaura (Coria and Salgado, 1996; Salgado et al., 1997), and Notohypsilophodon (Fig. 3D; Martínez, 1998), the humerus is superficially similar to CGM 30975. In the ornithopods, however, the proximal margin is sinuous or rounded rather than straight, the maximum concavity of the medial surface occurs near the midpoint of the shaft, and the distal region is medially positioned and notably less expanded than the proximal (Table 1). Moreover, in Notohypsilophodon, the deltopectoral crest is virtually absent (Fig. 3D; Martínez, 1998) while in Ouranosaurus and Gasparinisaura it extends far cranial to the margin of the shaft (Taquet, 1976; Coria and Salgado, 1996). In the humeri of the enigmatic rhabdodontid iguanodontians Rhabdodon and Zalmoxes from the Late Cretaceous of Europe, the proximal region is medially deflected and the shaft more robust than in CGM 30975 (Pereda-Suberbiola and Sanz, 1999; Weishampel et al., 2003). The humeri of the European hadrosaurs Telmatosaurus and Pararhabdodon differ strongly from CGM 30975 (Weishampel et al., 1993; Laurent et al., 1997). In the other ornithopods considered, the humerus is either too fragmentary for comparison (Casamiquela, 1964), undescribed (Hooker et al., 1991; Taquet and Russell, 1999) or unknown (Brett-Surman, 1979; Galton and Taquet, 1982; Bonaparte et al., 1984; Cooper, 1985; Powell, 1987; González-Riga and Casadío, 2000).

Dyrosaurid Affinities-Interestingly, Langston (1995) noted resemblances between the humeri of ornithopod dinosaurs and those of dyro-
A

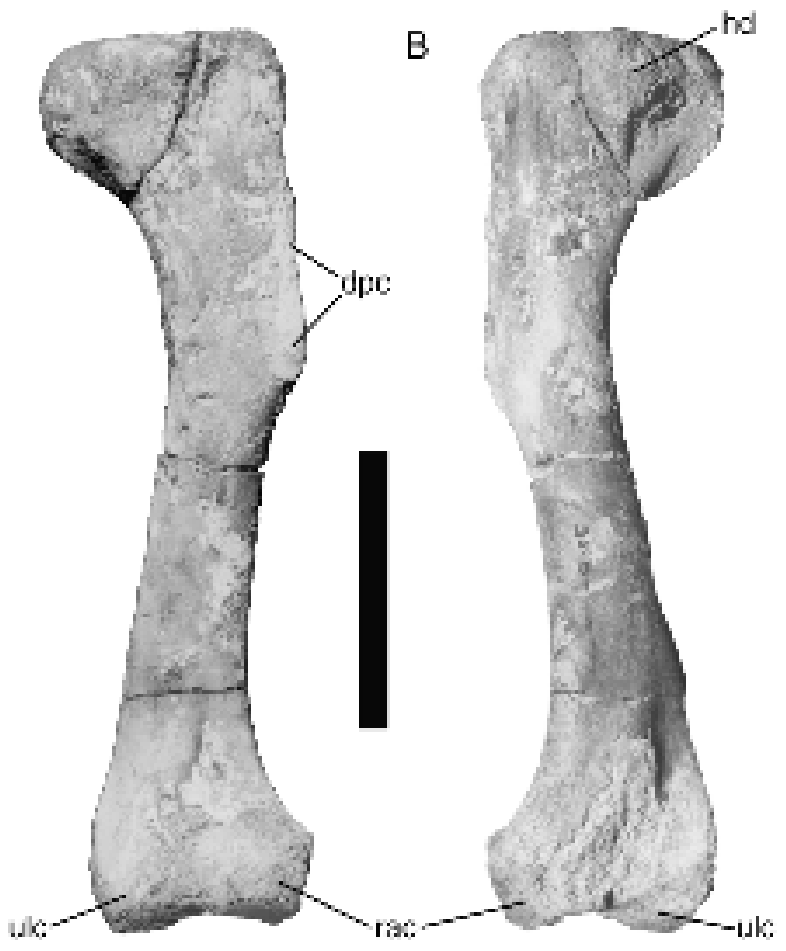

FIGURE 2. Dyrosaurid left humerus, CGM 30975. A, ventral (=cranial) view. B, dorsal ( = caudal) view. Scale equals $100 \mathrm{~mm}$.

saurid crocodyliforms. Indeed, CGM 30975 is strikingly similar to the humerus of the dyrosaurid Hyposaurus natator (YPM 985; Troxell, 1925) from the Maastrichtian of New Jersey (Fig. 3E), particularly in regard to the "squared" proximal region, the length and morphology of the deltopectoral crest, and the lateral deflection of the distal portion. Slight differences occur in the degree of expansion of the proximal and distal ends and the curvature of the shaft. However, because these features appear to become more pronounced with increasing size in dyrosaurids (Langston, 1995), and the humerus of YPM 985 is only 55\% the length of CGM 30975, we attribute these differences to the dimensions of the individuals involved. CGM 30975 also clearly resembles the humeri of the dyrosaurids Congosaurus bequaerti (MRAC 1813; Dollo, 1914; Swinton, 1950:pl. VI) from the Paleocene of Cabinda, Angola and Rhabdognathus sp. from the Paleocene of Saudi Arabia (USGS-SAP 33-CR-3 and 3-CR-1; Langston, 1995:fig. 24). The relative widths of the proximal and distal ends are similar in CGM 30975 and C. bequaerti (Table 1).

The provenance of CGM 30975 offers further evidence in support of a dyrosaurid identification. Dyrosaurids are known from Late CretaceousEocene coastal and estuarine deposits throughout North Africa and the Middle East (see Buffetaut, 1981). Skull fragments probably pertaining to the dyrosaurid Dyrosaurus are known from the Quseir Formation of southern Kharga Oasis (Churcher and Russell, 1992; Churcher, 1995). More material tentatively referred to Dyrosaurus has been recovered from the coeval Mut Formation of nearby Dakhleh Oasis (Churcher, 1995) and Late Cretaceous sediments elsewhere in Egypt (Gemmellaro, 1921).

Based on the sum of this evidence, we refer CGM 30975 to Dyrosauridae. Due to the limited amount of information available on diagnostic characters of the dyrosaurid appendicular skeleton, we are unable to determine the generic affinities of the Quseir specimen with certainty. Given the probable occurrence of Dyrosaurus in the same deposits, it is possible that CGM 30975 pertains to that taxon. Remarkably, along with the occurrences from Mali and Nigeria mentioned above, the Egyptian humerus represents a third putative post-Cenomanian North African ornithischian record that has proven dyrosaurid in origin.

Significance-The referral of CGM 30975 to Dyrosauridae invalidates the occurrence of Ornithischia in the post-Cenomanian Late Cretaceous of continental Africa. Because the African terrestrial vertebrate record for this interval is extremely poorly known, its lack of ornithischian 


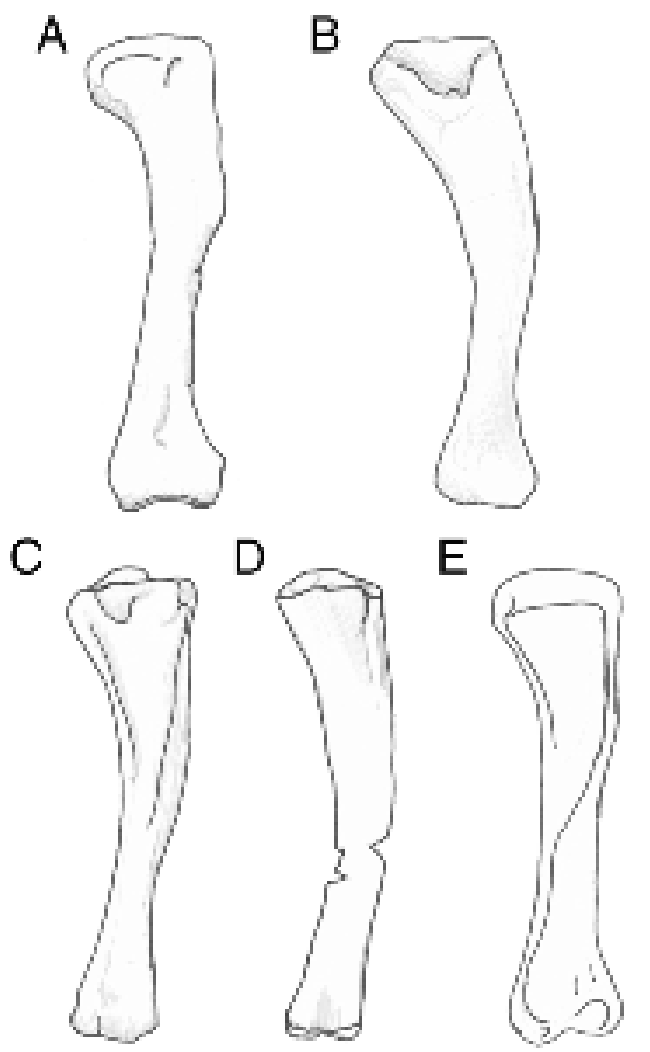

FIGURE 3. Dyrosaurid and ornithischian humeri, not to scale. A, CGM 30975 (Dyrosauridae). B, Goyocephale lattimorei (Pachycephalosauria; after Perle et al., 1982). C, Ouranosaurus nigeriensis (Ornithopoda; after Taquet, 1976). D, Notohypsilophodon comodorensis (Ornithopoda; after Martínez, 1998). E, Hyposaurus natator, YPM 985 (Dyrosauridae; after Troxell, 1925). A, C-E in ventral (=cranial) view; B in dorsal ( = caudal) view.

dinosaurs is probably a consequence of incomplete sampling. Intriguingly, however, ornithischians are also not yet known from increasingly well-studied latest Cretaceous deposits in adjacent Madagascar (e.g., Krause et al., 1999; Buckley et al., 2000).

Similarly, Indo-Pakistan, which remained connected to Madagascar until the early Coniacian (approximately 88.0 Ma, Storey et al., 1995) has not produced definitive Late Cretaceous ornithischian material to date. Mohabey (1989) described a dinosaurian element that he identified as a braincase from Upper Cretaceous sediments in the western Indian state of Gujarat. He referred this specimen to Ornithischia, but regarded this referral as doubtful. Another specimen from Gujarat, a hollow fragment that Dwivedi and Ghevariya (1984) interpreted as a ceratopsid horncore, may instead pertain to a theropod limb element or a dorsal rib of a theropod or titanosauriform sauropod. Moreover, reports of a fragmentary ornithopod skeleton from the Late Cretaceous of southern India (Narayan Rao and Sesachar, 1927; Molnar, 1980) have never been confirmed.

TABLE 1. Humeral dimensions $(\mathrm{mm})$ in the dyrosaurid crocodyliforms CGM 30975 and Congosaurus bequaerti and the iguanodontian ornithopod Ouranosaurus nigeriensis. Data for C. bequaerti and O. nigeriensis from Swinton (1950) and Taquet (1976), respectively.

\begin{tabular}{lccc}
\hline & CGM & $\begin{array}{c}\text { Congosaurus } \\
\text { bequaerti }\end{array}$ & $\begin{array}{c}\text { Ouranosaurus } \\
\text { nigeriensis }\end{array}$ \\
\hline Proximodistal length & 315 & 295 & 555 \\
Maximum proximal width & 86 & 85 & 145 \\
Maximum distal width & 79 & 81 & 102 \\
Proximal/distal width & 1.09 & 1.05 & 1.42
\end{tabular}

Claims of thyreophoran (stegosaurian or ankylosaurian) remains from the Indian Late Cretaceous are relatively common, but all remain unsubstantiated. The putative stegosaur Brachypodosaurus was described from an isolated limb element identified as a humerus from the Maastrichtian Lameta Formation of Madhya Pradesh (Chakravarti, 1934). Nevertheless, Galton (1981) could not confirm the identity of the holotype element, and consequently, the affinities of the taxon. Dravidosaurus, another purported stegosaur from Coniacian deposits in Tamilnadu (Yadagiri and Ayyasami, 1979), was recently suggested to pertain to Plesiosauria (Chatterjee and Rudra, 1996). Wilson et al. (2003) cast further doubt on the stegosaurian affinities of Brachypodosaurus and Dravidosaurus, noting that these taxa do not exhibit synapomorphies of that clade. Matley (1923) and Huene and Matley (1933) described a supposed ankylosaur, Lametasaurus, from the Lameta Formation, but this taxon was subsequently shown to be based upon a chimera of theropod, sauropod, and possibly crocodyliform material (Chakravarti, 1935; Galton, 1981; Molnar and Frey, 1987; Chatterjee and Rudra, 1996; Wilson et al., 2003). Coombs (1978), Yadagiri and Ayyasami (1979), and Chatterjee and Rudra (1996) mentioned additional reputed thyreophoran material from the Upper Cretaceous of India, but these remains have never been described. Finally, despite a recent increase in research there, ornithischians remain unrecorded from Late Cretaceous deposits in Pakistan (Wilson et al., 2001).

The current lack of unquestionable ornithischian dinosaur material from the post-Cenomanian Late Cretaceous of Africa, Madagascar, and Indo-Pakistan contrasts contemporaneous dinosaurian faunas of most other Gondwanan continents, from which ornithopods and ankylosaurs are known (e.g., Bonaparte et al., 1984; Gasparini et al., 1987, 1996; Wiffen and Molnar, 1989; Hooker et al., 1991; Molnar and Wiffen, 1994; Coria and Salgado, 1996, 2001; Salgado and Coria, 1996; Case et al., 2000; González Riga and Casadio, 2000). Even if genuine, however, this ornithischian absence is not necessarily reflective of a common origin for the Late Cretaceous terrestrial vertebrate assemblages of Africa, Madagascar, and Indo-Pakistan. Nevertheless, it is notable in light of recent hypotheses of Late Cretaceous tetrapod dispersal and resultant faunal affinity between South America, Antarctica, Madagascar, and IndoPakistan, and endemism in African assemblages during this interval (e.g., Sampson et al., 1998; Krause et al., 1999; Buckley et al., 2000). An improved understanding of the reality and significance of the apparent Late Cretaceous ornithischian absence from Africa, Madagascar, and IndoPakistan is contingent upon continued research in these areas.

Acknowledgments-We thank K. Soleiman, M. Said Abdel-Ghani, Y. Abdel-Razik Ahmed, and A. Swedan for permission to study and access to CGM 30975. J. R. Smith provided a locus map modified to become Figure 1. P. Kane-Vanni assisted with the study of the specimen and provided the illustrations in Figure 3. MCL benefited from discussions with C. Brochu, E. Buffetaut, R. Coria, R. Denton, B. Grandstaff, J. D. Harris, J. M. Harris, L. Jacobs, W. Langston, Jr., N. Mateer, R. Molnar, D. Parris, D. Pol, D. Russell, G. Storrs, A. Tumarkin-Deratzian, D. Weishampel, and J. Wilson. Early drafts of the manuscript benefited from comments by J. D. Harris. C. Brochu and two anonymous referees provided valuable reviews that improved the final manuscript. The Bahariya Dinosaur Project (BDP) has been supported by Cosmos Studios, MPH Entertainment, the University of Pennsylvania, the Andrew W. Mellon Foundation, the late Emilie de Hellebranth, and the Delaware Valley Paleontological Society. This paper is BDP Contribution 4.

\section{LITERATURE CITED}

Arambourg, C., and R. G. Wolff. 1969. Nouvelles données paléontologique sur l'âge des "Grès du Lubur" (Turkana Grits) à l'ouest du lac Rodolphe. Comptes Rendus Sommaire des Séances de la Société Géologique de France 3-4:190-192.

Arua, I., and V. R. Rao. 1987. New stratigraphic data on the Eocene Ameki Formation, southeastern Nigeria. Journal of African Earth Sciences 6:391-397.

Awad, G. H., and M. G. Ghobrial. 1966. Zonal stratigraphy of the Kharga Oasis. General Egyptian Organization for Geological Research and Mining, Paper 34:77 pp.

Bonaparte, J. F., M. R. Franchi, J. E. Powell, and E. G. Sepulveda. 1984 La Formacíon Los Alamitos (Campaniano-Maastrichtiano) del sudeste de Río Negro, con descripción de Kritosaurus australis n. sp. (Hadrosauridae). Significado paleogeográfico de los vertebrados. Asociacion Geologica Argentina, Revista 39:284-299. 
Brett-Surman, M. K. 1979. Phylogeny and palaeobiogeography of hadrosaurian dinosaurs. Nature 277:560-562.

Buckley, G. A., C. A. Brochu, D. W. Krause, and D. Pol. 2000. A pugnosed crocodyliform from the Late Cretaceous of Madagascar. Nature 405:941-944.

Buffetaut, E. 1981. Radiation évolutive, paléoécologie et biogéographie des crocodiliens mésosuchiens. Mémoires de la Société Géologique de France 60:1-85.

Casamiquela, R. M. 1964. Sobre un dinosaurio hadrosaurido de la Argentina. Ameghiniana 3:285-308.

Case, J. A., J. E. Martin, D. S. Chaney, M. Reguero, S. A. Marenssi, S. Santillana, and M. O. Woodburne. 2000. The first duck-billed dinosaur (Family Hadrosauridae) from Antarctica. Journal of Vertebrate Paleontology 20:612-614.

Chakravarti, D. K. 1934. On a stegosaurian humerus from the Lameta beds of Jubbulpore. Quarterly Journal of the Mineralogical and Metallurgical Society of India 30:75-79.

Chakravarti, D. K. 1935. Is Lametasaurus indicus an armored dinosaur? American Journal of Science, 5th series 30:138-142.

Chatterjee, S., and D. K. Rudra. 1996. KT events in India: impact, rifting, volcanism and dinosaur extinction. Memoirs of the Queensland $\mathrm{Mu}-$ seum 39:489-532.

Churcher, C. S. 1995. Giant Cretaceous lungfish Neoceratodus tuberculatus from a deltaic environment in the Quseir (= Baris) Formation of Kharga Oasis, Western Desert of Egypt. Journal of Vertebrate Paleontology 15(4):845-849.

Churcher, C. S., and D. A. Russell. 1992. Terrestrial vertebrates from Campanian strata in Wadi El-Gedid (Kharga and Dahkleh Oases), Western Desert of Egypt. Journal of Vertebrate Paleontology 12(3, supplement):23A.

Coombs, W. P., Jr. 1978. The families of the ornithischian dinosaur order Ankylosauria. Palaeontology 21:143-170.

Cooper, M. R. 1985. A revision of the ornithischian dinosaur Kangnasaurus coetzeei Haughton, with a classification of the Ornithischia. Annals of the South African Museum 95:281-317.

Coria, R. A., and J. O. Calvo. 2002. A new iguanodontian ornithopod from Neuquén Basin, Patagonia, Argentina. Journal of Vertebrate Paleontology 22:503-509.

Coria, R. A., and L. Salgado. 1996. A basal iguanodontian (Ornithischia: Ornithopoda) from the Late Cretaceous of South America. Journal of Vertebrate Paleontology 16:445-457.

Coria, R. A., and L. Salgado. 2001. South American ankylosaurs; pp. 159-168 in K. Carpenter (ed.) The Armored Dinosaurs, Indiana University Press, Bloomington.

Demathieu, G. R., and P. Wycisk. 1990. Tetrapod trackways from southern Egypt and northern Sudan. Journal of African Earth Sciences 10:435-443.

Dollo, L. 1914. Sur la découverte de Téléosauriens tertiares au Congo. Académie Royale des Sciences, des lettres et des beaux-arts de Belgique, Bulletin:288-298.

Dwivedi, G. N., and Z. G. Ghevariya. 1984. Discovery of dinosaurian horn-core from the infra-trappean rocks of Kheda District, Gujarat. Current Science 53:1148-1150.

El-Kashab, B. 1977. A review of the fossil reptile faunas of Egypt. Geological Survey of Egypt and Mining Authority, Paper 62:1-9.

Furon, R. 1963. The Geology of Africa. Oliver and Boyd, London, 377 pp.

Galton, P. M. 1981. Craterosaurus pottonensis Seeley, a stegosaurian dinosaur from the Lower Cretaceous of England, and a review of Cretaceous stegosaurs. Neues Jahrbuch für Geologie und Palaeontologie, Abhandlungen 161:28-46.

Galton, P. M., and P. Taquet. 1982. Valdosaurus, a hypsilophodontid dinosaur from the Lower Cretaceous of Europe and Africa. Géobios 15:147-159.

Gasparini, Z., E. Olivero, R. Scasso, and C. Rinaldi. 1987. Un ankylosaurio (Reptilia, Ornithischia) Campaniano en el continente Antartico. Anais do X Congresso Brasileiro de Paleontologia 1:131-141.

Gasparini, Z., X. Pereda-Suberbiola, and R. E. Molnar. 1996. New data on the ankylosaurian dinosaur from the Late Cretaceous of the Antarctic Peninsula. Memoirs of the Queensland Museum 39: 583-594.

Gemmellaro, M. 1921. Rettili maëstrichtiani d' Egitto. Giornale di Scienze Naturali ed Economiche 32:339-351.

Gomani, E. M. 1999. Dinosaurs of the Cretaceous sedimentary rocks of northern Malawi, Africa. Unpublished Ph.D. dissertation, Southern Methodist University, Dallas, $257 \mathrm{pp}$.

González-Riga, B. J., and S. Casadío. 2000. Primer registro de Dinosauria (Ornithischia, Hadrosauridae) en la provincia de La Pampa (Argentina) y sus implicancias paleobiogeográficas. Ameghiniana 37: 341-351.

Hay, O. P. 1930. Second Bibliography and Catalog of the Fossil Vertebrata of North America. Volume 2. Carnegie Institute, Washington, Publication 390

Hendriks, F., P. Luger, J. Bowitz, and H. Kallenbach. 1987. Evolution of the depositional environments of S-E Egypt during the Cretaceous and Lower Tertiary. Berliner Geowissenschaftliche Abhandlungen, Reihe A 75:49-82.

Hooker, J. J., A. C. Milner, and S. E. K. Sequeira. 1991. Short note: an ornithopod dinosaur from the Late Cretaceous of west Antarctica. Antarctic Science 3:331-332.

Huene, F. von, and C. A. Matley. 1933. The Cretaceous Saurischia and Ornithischia of the central provinces of India. Palaeontologica Indica 21:1-74.

Jacobs, L. L., D. A. Winkler, and E. M. Gomani. 1996. Cretaceous dinosaurs of Africa: examples from Cameroon and Malawi. Memoirs of the Queensland Museum 39:595-610.

Krause, D. W., R. R. Rogers, C. A. Forster, J. H. Hartman, G. A. Buckley, and S. D. Sampson. 1999. The Late Cretaceous vertebrate fauna of Madagascar: implications for Gondwanan paleobiogeography. GSA Today 9:1-7.

Klitzsch, E., J. C. Harms, A. Lejal-Nicol, and F. K. List. 1979. Major subdivisions and depositional environments of Nubia strata, southwestern Egypt. AAPG Bulletin 63:967-974.

Langston, W. 1995. Dyrosaurs (Crocodilia, Mesosuchia) from the Paleocene Umm Himar Formation, Kingdom of Saudi Arabia. U.S. Geological Survey Bulletin 2093:F1-F36.

Laurent, Y., J. Le Loeuff, and E. Buffetaut. 1997. Les Hadrosauridae (Dinosauria, Ornithopoda) du Maastrichtien supérieur des Corbières orientales (Aude, France). Revue de Paléobiologie, Genève 16:411-423.

Mahmoud, M. S. 1998. Palynological dating of the Quseir Formation, Kharga Oasis (Egypt). Arab Gulf Journal of Scientific Research 16:267-281.

Martínez, R. D. 1998. Notohypsilophodon comodorensis gen. et sp. nov. un Hypsilophodontidae (Ornitischia: Ornithopoda) del Cretacico Superior de Chubut, Patagonia central, Argentina. Acta Geologica Leopoldensia 21:119-135.

Mateer, N. J., Wycisk, L. L. Jacobs, M. Brunet, P. Luger, M. A. Arush, F. Hendriks, T. Weissbrod, G. Gvirtzman, E. Mbede, A. Dina, R. T. J. Moody, G. Weigelt, H. A. El-Nakhal, J. Hell, and J. Stets. 1992. Correlations of nonmarine Cretaceous strata of Africa and the Middle East. Cretaceous Research 13:273-318.

Matley, C. A. 1923. Note on an armoured dinosaur from the Lameta beds of Jubbulpore. Records of the Geological Survey of India 55: 105-109.

Mohabey, D. M. 1989. The braincase of a dinosaur from the Late Cretaceous Lameta Formation, Kheda District, Gujarat, Western India. Indian Journal of Earth Sciences 16:132-135.

Molnar, R. 1980. Australian Late Mesozoic terrestrial tetrapods: some implications. Mémoires de la Société Géologique de France, N.S. 139:131-143.

Molnar, R., and E. Frey. 1987. The paravertebral elements of the Australian ankylosaur Minmi (Reptilia: Ornithischia, Cretaceous). Neues Jahrbuch für Geologie und Paläontologie, Abhandlungen 175:19-37.

Molnar, R., and J. Wiffen. 1994. A Late Cretaceous polar dinosaur fauna from New Zealand. Cretaceous Research 15:689-706.

Narayan Rao, C. R., and B. R. Seshachar. 1927. A short note on certain fossils taken in the Ariyalur area (S. India). Half Yearly Journal of of Mysore University 2:144-152.

Nopcsa, F. 1925. On some reptilian bones from the Eocene of Sokoto. Geological Survey of Nigeria, Occasional Paper 2:1-16.

Pereda-Suberbiola, X., and J. L. Sanz. 1999. The ornithopod dinosaur Rhabdodon from the Upper Cretaceous of Laño (Iberian Peninsula). Estudios del Museo de Ciencias Naturales de Alava 14: 257-272.

Perle, A., T. Maryańska, and H. Osmólska. 1982. Goyocephale lattimorei gen. et sp. n., a new flat-headed pachycephalosaur (Ornithischia, 
Dinosauria) from the Upper Cretaceous of Mongolia. Acta Paleontologica Polonica 27:115-127.

Powell, J. E. 1987. Hallazgo de un dinosaurio hadrosaurido (Ornithischia, Ornithopoda) en la Formación Allen (Cretácico Superior) de Salitral Moreno, Provincia de Río Negro, Argentina; pp. 149-152 in F. G. Aceñolaza (ed.) Actas del Decímo Congreso Geológico Argentino.

Salgado, L., and R. A. Coria. 1996. First evidence of an ankylosaur (Dinosauria, Ornithischia) in South America. Ameghiniana 33:367-371.

Salgado, L., R. A. Coria, and S. E. Heredia. 1997. New materials of Gasparinisaura cincosaltensis (Ornithischia, Ornithopoda) from the Upper Cretaceous of Argentina. Journal of Paleontology 71:933-940.

Sampson, S. D., L. M. Witmer, C. A. Forster, D. W. Krause, P. M. O'Connor, P. Dodson, and F. Ravoavy. 1998. Predatory dinosaur remains from Madagascar: implications for the Cretaceous biogeography of Gondwana. Science 280:1048-1051.

Stefano, G. de 1903. Nuovi rettili degli strati a fosfato della Tunisia. Bollettino della Societa Geologica Italiana 22:51-80, pl. IV.

Storey, M., J. J. Mahoney, A. D. Saunders, R. A. Duncan, S. P. Kelley, and M. F. Coffin. 1995. Timing of hot spot-related volcanism and the breakup of Madagascar and India. Science 267:852-855.

Swinton, W. E. 1930. On fossil Reptilia from Sokoto Province. Bulletin of the Geological Survey of Nigeria 13:1-56.

Swinton, W. E. 1950. On Congosaurus bequaerti Dollo. Annales du Musée du Congo belge (Tervuren, Belgique) 4:1-35.

Taquet, P. 1976. Géologie et paléontologie de gisement de Gadoufaoua. Cahiers de Paléontologie 1-191.

Taquet, P., and D. A. Russell. 1999. A massively-constructed iguanodont from Gadoufaoua, Lower Cretaceous of Niger. Annales de Paleontologie 85:85-96.

Troxell, E. L. 1925. Hyposaurus, a marine crocodilian. American Journal of Science 5th ser. 9:489-514.

Walker, A. D. 1970. A revision of the Jurassic reptile Hallopus victor
(Marsh), with remarks on the classification of crocodiles. Philosophical Transactions of the Royal Society of London B 257:323-371.

Weishampel, D. B. 1990. Dinosaurian distribution, pp. 63-139 in D. B. Weishampel, P. Dodson, and H. Osmolska (eds.), The Dinosauria. University of California Press, Berkeley.

Weishampel, D. B., C.-M. Jianu, Z. Csiki, and D. B. Norman. 2003. Osteology and phylogeny of Zalmoxes (n. g.), an unusual euornithopod dinosaur from the latest Cretaceous of Romania. Journal of Systematic Palaeontology 1:65-123.

Weishampel, D. B., D. B. Norman, and D. Grigorescu. 1993. Telmatosaurus transsylvanicus from the Late Cretaceous of Romania: the most basal hadrosaurid dinosaur. Palaeontology 36:361-385.

Wescott, W. A., C. K. Morley, and F. M. Karanja. 1993. Geology of the "Turkana Grits" in the Lariu range and Mt. Porr areas, southern Lake Turkana, northwestern Kenya. Journal of African Earth Sciences 16:425-435.

Whetstone, K. N., and P. J. Whybrow. 1983. A 'cursorial' crocodilian from the Triassic of Lesotho (Basutoland), southern Africa. Occasional Papers of the Museum of Natural History 106:1-37.

Wiffen, J., and R. E. Molnar. 1989. An Upper Cretaceous ornithopod from New Zealand. Géobios 22:531-536.

Wilson, J. A., M. S. Malkani, and P. D. Gingerich. 2001. New crocodyliform (Reptilia, Mesoeucrocodylia) from the Upper Cretaceous Pab Formation of Vitakri, Balochistan (Pakistan). Contributions from the Museum of Paleontology of the University of Michigan 30: 321-336.

Wilson, J. A., P. C. Sereno, S. Srivastava, D. K. Bhatt, A. Khosla, and A. Sahni. 2003. A new abelisaurid (Dinosauria, Theropoda) from the Lameta Formation (Cretaceous, Maastrichtian) of India. Contributions from the Museum of Paleontology of the University of Michigan 31:1-42.

Yadagiri, P., and K. Ayyasami. 1979. A new stegosaurian dinosaur from Upper Cretaceous sediments of south India. Journal of the Geological Society of India 20:521-530. 